\title{
Transformative impacts of globalization on the economy of South Caucasus and Central Asia ${ }^{1}$
}

\author{
Mushfig Guliyev ${ }^{1, *}$, Khatira Huseynova ${ }^{2}$ \\ ${ }^{1}$ Azerbaijan State University of Economics (UNEC), Faculty of Economics, Department of \\ International Economics, Istiqlaliyyat str.6, AZ 1001 Baku, Azerbaijan \\ ${ }^{2}$ The Academy of Public Administration under the President of the Republic of Azerbaijan, Faculty of \\ Administrative Management, Lermontov str. 74, AZ 1001, Baku, Azerbaijan
}

\begin{abstract}
.
Research background: The disappointing economic results of the global economic crises, which brought macroeconomic instability, increasing inequality, are often understood as results of globalization. In this article, besides the positive effects, the many unavoidable negative impacts of globalization on the South Caucasus and Central Asia region are discussed. It is shown that responsibility for the economic crisis is not entirely globalization but a combination of the raw material based economy, together with incorrect trade policy. In this article, an alternative view of globalization is offered, including diversification policy challenges. It also explores the main tools of dissemination of globalization, which has created many new opportunities for business in the region.

Purpose of the article: The aim is to find out to what extent the countries are involved in international integration, comparative analysis transformative impacts of globalization.

Methods: The methods of comparative analysis and systematization of scientific approaches were employed. The research contains an analysis of the region's position in the international trade and investment.

Findings \& Value added: The region has to concentrate on a new picture of the multipolar world. In the region countries, the processes of globalization were accelerated after the countries became a member of WTO, ADB and integration into the international relations. The findings in general correspond with the trends in emerging markets that the process of globalization is gradually turning into functional mechanism of competitiveness, but there are some differences. The impacts of globalization process are progressively increasing, also there are new unforeseen impacts evolving.
\end{abstract}

Keywords: Globalization; WTO; China's Belt and Road Initiative (BRI); The Eastern Partnership; South Caucasus and Central Asia

JEL Classification: $F 02 ; F 13 ; F 15 ; F 63 ; O 19$

\footnotetext{
${ }^{1}$ Abbreviations \& acronyms: South Caucasus $(\mathrm{SC})=$ Armenia, Azerbaijan, Georgia; Central Asia (CA)

= Kazakhstan, the Kyrgyz Republic, Tajikistan, Turkmenistan and Uzbekistan.

*Corresponding author: guliyev.my@gmail.com
} 


\section{Introduction}

Contemporary observers and researchers dig deeper into what consequences globalization will have for the future of the the World economy and its subregions. The global economy connected countries around the globe, as history shown globalization disrupts some livelihoods while opening new and better opportunities. Joseph Stiglitz, frequent critic of globalization, has nonetheless observed that globalization "has reduced the sense of isolation felt in much of the developing world and has given many people in the developing world access to knowledge" [1]. The neoliberal turn in the 1990s, (or what in the context of the Bretton Woods institutions often is termed a 'Washington Consensus'), overturned post-war agreement on the importance of embedding markets in national and international public institutions and raised questions about their long-term viability and legitimacy; Dissatisfaction with its neoliberalism and good governance commitments in the 1990s led emerging powers to engage in practices of 'counter-multilateralism' and establish organizations like the New Development Bank (NDB) and the Asian Infrastructure Investment Bank (AIIB) as alternative sources of funding [2]. Globalization, the increasing complexity of the world economy and changing regional economic landscapes brings opportunities as well as risks.

The South Caucasus and Central Asia (SC\&CA) is a region often viewed through a narrow globalization lens. But the region has untapped potential to play an important economic role in the world economy. The World Economic Forum initiated the Scenarios for the South Caucasus and Central Asia, such as: In the future, the region has the potential to establish a fresh identity as a centre of activity within a new, 21st-century economy [3]. But how best to pursue their economic objectives in transforming this potential into reality, what role their immediate neighbours will play in supporting their aspirations, what new partnerships must be aspired to in the era of transformation and how regional relations can best be shaped to maximize collective interactions benefits? By answering these critical questions about the region's longer-term future the South Caucasus and Central Asia countries can develop robust strategies for their institutional choices and spatial transformation under globalization. SC\&CA is situated on the traditional Silk Road trading road, midway between Europe and the countries of east, south and southeast Asia. In spite of this strategic location, Central Asian countries are poorly connected, both to one another and to the rest of the world. The main factors of poor connectivity: The region countries are landlocked; Central Asia is remote from both European and Eastern developed markets; Protectionist economic policies have created high barriers to foreign investment.

South Caucasus and Central Asia is among the world regions that are least explored in terms of their spatial transformation and regional cooperation. Behind the rhetoric of regional cooperation, the Central Asian states have been embroiled with increasing frequency in conflicts among themselves, including trade wars, border disputes and disagreements over the management and use of water and energy resources [4]. Limited domestic political reform in the region comes against a backdrop of difficult internal and external conflict and tension, which only further complicate the business environment and integration. The post-Soviet period has been characterized by internal conflicts in much of the CIS region, especially in $\mathrm{SC} \& \mathrm{CA}^{2}$. This paper focuses on the way in which changes globally are shaping the regional

\footnotetext{
${ }^{2}$ Post-Soviet Conflicts in SC\&CA (Initiation, Resolution Status, International Mediation):

Violent Conflicts: Azerbaijan/Nagorno-Karabakh/Armenia (02/1988-11/2020, ceasefire, Russia/OSCE/Minsk Group); Georgia/Abkhazia (04/1989, ceasefire, Russia/CIS/UN/OSCE); Georgia/South Ossetia (01/1991, settlement, Russia/OSCE); Tajikistan (05/1992-04/1999, settlement, Russia/CIS/OSCE).

Non-Violent Conflicts: Uzbekistan/Ferghana Valley ( 06/1989, control regime, No); Northern Kazakhstan (01/1992, control regime, No); Georgia/Ajaria (01/1991, constitutional autonomy, No)
} 
interactions, as well as the countries' capacity to meet the challenges and difficulties arising from two systemic factors - globalisation and integration.

Under globalization South Caucasus countries - Armenia, Azerbaijan, and Georgia have chosen different transformation paths for political and economic development. The region countries borders have to various degrees have emerged as obstacles to cooperation. The differences into coherent bilateral and multilateral policies in the South Caucasus: Georgia in 2013 has come significantly closer to the EU through the EaP (by signing an Association Agreement (AA)); Armenia has become a member of the EAEU, which entered into effect in 2015; Azerbaijan has so far not engaged into any legally-binding economic integration project. Over the past few years, the simultaneous deployment of two mutually exclusive projects - the Deep and Comprehensive Free-Trade Areas (DCFTAs) offered by the EU as part of its Eastern Partnership (EaP) and the Russian-led Eurasian Economic Union (EEU) has only exacerbated differences in the South Caucasus [5].

As the so-called 'Asian Century' unfolds, Central Asian countries are increasingly directing their foreign relations eastward. A regionalized system of global cooperation is include major and emerging powers. This implies that the new face of globalization led more by the East than the West. US, emerging powers and regional actors must pursue to promote stability in this decentred but interdependent, "multiplex world" [6]. In terms of multilateralism, Central Asia is increasingly enmeshed in a web of overlapping institutions with a strong Asian identity, coexisting with the region's Western institutional references [7]. Main of the Central Asia's eastward tilt is its growing involvement in a variety of pan-Asian multilateral frameworks: the Conference on Interaction and Confidence Building Measures in Asia (CICA), the Shanghai Cooperation Organization (SCO) in the area of security, and, most recently, the Asian Infrastructure Investment Bank (AIIB) and, to even the certain extent the Eurasian Economic Union (EEU) in the economic sphere, which the most promising conceptual avenues for such an endeavor. Some countries are part of several regional agreements and regional spaces are also eager to develop trade links with other regional blocs, following the rules of trade multilateralism [8]: The logical conclusion is that this further promotes global trade liberalization, rather than threatening or slowing it, together these networks are help to promote globalization. As a keen participant in Eurasian connectivity initiatives, Kazakhstan has called for closer coordination between the three major players: the EU, China and the EAEU. The space of interactions has been shaped by the as well as the region's recent reemergence as a hub between West-East -between Russia, China, EU, and the Middle East. For the region, the EU's and China's very different approaches and both offer potential benefits.

The emergence of China as a major global trading nation has certainly had a significant effect on the overall openness of other countries. Other authors have already offered evaluations of the impact of China on the first moment of income, that is, via the classic gains from trade, its impact on local labor markets and its influence on innovation. Contrary to this common wisdom, they argue that openness to international trade can lower income volatility by reducing exposure to domestic shocks and allowing countries to diversify the sources of demand and supply across countries and they assess the importance of the two mechanisms (sectoral specialization and cross-country diversification) and show that in recent decades international trade has reduced economic volatility for most countries. [9]. In 2013, Chinese President, Xi Jinping, announced a Silk Road Economic Belt (the project has been re-branded as the Belt and Road Initiative (BRI) - which some already confer a title on Chine's Marshall Plan for development Asia. Yet embracing the BRI is not without risks [10]: Some BRI investments may prove to be economically unviable, and socially and environmentally harmful, in another hand, inadequate cross-border coordination could render some BRI investments wasteful. SC\&CA is still a key part of the project. SC\&CA countries naturally view this massive development program as a unique opportunity to accelerate their economic 
development through increased foreign investment and tighter economic relationships with their neighbors. After infrastructure investments by China and transit countries brought the journey time down to less than two weeks, three times faster than by sea; for a container of goods, whose value may reach hundreds of thousands of dollars, rail freight costs of a few thousand dollars [11].

Economic globalization has increased at a faster pace since the mid-nineties, especially for the least open country; the increase in social globalization is slightly less pronounced, while political globalization saw a period of faster increase in the early nineties [12].There are major differences across SC\&CA countries in the degree to which they have succeeded in trade and economic transformation (table 1). International trade helps to discover and develop new productive capabilities and to increase domestic value added. Over an extended period, Azerbaijan has on average been particularly successful in diversifying its energy exports infrastructure to Europe, particularly in comparison with CA. Much of the progress has occurred through cooperation along the Georgia and Turkey that is, through entry into completely new phase.

Table 1. Indicators for Economic Transformation of SC\&CA region countries integrating into the world economy

\begin{tabular}{|l|c|c|c|c|c|c|}
\hline \multicolumn{1}{|c|}{ Countries } & $\begin{array}{c}\text { GDP } \\
\text { (million } \\
\$, 2018)\end{array}$ & $\begin{array}{c}\text { GDP } \\
\text { per } \\
\text { capita } \\
(\$, 2016- \\
2018)\end{array}$ & $\begin{array}{c}\text { Average Annual } \\
\text { Ratio of net FDI } \\
\text { inflows to GDP } \\
(\%, 2001-2014)\end{array}$ & $\begin{array}{c}\text { Trade } \\
(\% \text { GDP, } \\
2016- \\
2018)\end{array}$ & $\begin{array}{c}\text { Exports, } \\
\text { f.o.b. } \\
(2018)\end{array}$ & $\begin{array}{c}\text { Imports, } \\
\text { c.i.f } \\
(2018)\end{array}$ \\
\hline Azerbaijan & 45418 & 4225 & 8.9 & 45.8 & 21500 & 11000 \\
\hline Armenia & 12411 & 3844 & 5.6 & 42.1 & 2412 & 4963 \\
\hline Georgia & 16324 & 4100 & 8.4 & 55.4 & 3354 & 9119 \\
\hline Kazakhstan & 170539 & 8624 & 8.2 & 30.1 & 60956 & 32534 \\
\hline $\begin{array}{l}\text { Kyrgyz } \\
\text { Republic }\end{array}$ & 8093 & 1204 & 5.1 & 50.5 & 1765 & 4907 \\
\hline Tajikistan & 7520 & 808 & 4.2 & 27.8 & 1209 & 2447 \\
\hline Turkmenistan & 44114 & 6905 & 8.5 &.. & 10000 & 2500 \\
\hline Uzbekistan & 41241 & 1631 & 1.8 & 27.1 & 11218 & 17306 \\
\hline
\end{tabular}

Source: Compiled by the authors

Strong macroeconomic policies are needed to help the SC\&CA countries reap the benefits of globalization on output growth over time. Given these indicators, it may be informative to look at structural transformation patterns and trade activity of the region countries. The countries of the Caucasus and Central Asia (SC\&CA) have achieved stronger growth than countries in other regions, though this growth has been relatively volatile and gains in output have been driven mostly by commodity and labor exports, reflecting the highly undiversified economies of most SC\&CA countries [13]. SC\&CA oil and gas exporters (Azerbaijan, Kazakhstan, Turkmenistan, and Uzbekistan) have achieved improvements in living standards with the use of their nature wealth. Azerbaijan, Kazakhstan, Turkmenistan is particularly well endowed in energy wealth and keen to explore its natural wealth in a sustainable manner. FDI inflows varied considerably over time and across SC\&CA countries (Table 1). Investments in the oil\&gas nations of SC\&CA were concentrated in a limited number of largescale projects. According to the ADB (2019), most FDI inflows went to the energy and mining sectors, although FDI shares in countries, such as Georgia, were largest in sectors such as finance, transport, and communication. Growth in the SC\&CA region has been relatively volatile, slightly more so for oil importers. Commodity exports account for 45 to 70 percent of export revenues for SC\&CA oil exporters. SC\&CA oil importers rely on other commodities for their export revenues (for example, 10 to 20 percent of revenues from nonferrous metals for Armenia and Georgia) or on workers' remittances (in particular, 
Tajikistan and the Kyrgyz Republic) [14]. According to the IMF (2014), the countries in the Caucasus and Central Asia have recorded significant macroeconomic achievements since independence. But SC\&CA countries face other common challenges arising from still weak regional cooperation, low global integration, and the relatively slow pace of structural reforms.

These are all critical to strengthen SC\&CA countries' ties to each other and the rest of the world, which would help drive diversification and growth. With world growth already slowing, SC\&CA countries are vulnerable to volatile oil prices, escalating global trade tensions, and deteriorating risk sentiment. This raises the urgency for diversifying economies. There is also evidence that diversified its trade partners away from the region (Table 2). Statistics highlight a pattern of growth in merchandise trade between countries of Central Asia, EU and those of other subregions of Asia. China was the first trading partner for Turkmenistan and Uzbekistan and the second for Kazakhstan; South Korea was Kazakhstan's fourth; Turkey was the first Tajikistan's, fourth Uzbekistan's, fifth for Kyrgyzstan and Turkmenistan partner. In the South and West Asian context, the leading trading partner is Islamic Republic of Iran and Turkey.

Table 2. How is South Caucasus \& Central Asia integrating into global trade?

\begin{tabular}{|c|c|c|c|c|}
\hline \multirow[t]{2}{*}{ Countries } & \multicolumn{2}{|c|}{$\begin{array}{c}\text { Rank in world trade } \\
\text { (2018), } \\
\text { Merchandise }\end{array}$} & \multicolumn{2}{|c|}{ Breakdown in economy's total exports,\% (2018) } \\
\hline & Exports & Imports & $\begin{array}{l}\text { By main commodity } \\
\text { group }\end{array}$ & By main destination \\
\hline Azerbaijan & $\begin{array}{c}70 \\
49^{\mathrm{a}} \\
0.11^{\mathrm{b}} \\
\end{array}$ & $\begin{array}{r}96 \\
71^{\mathrm{a}} \\
0.06^{\mathrm{c}} \\
\end{array}$ & $\begin{array}{l}\text { Agricultural: } 4.6 ; \\
\text { Fuels and mining: } \\
\text { 91.7; Manufactures: } \\
\text { 2.8; Other: } 0.8\end{array}$ & $\begin{array}{l}\text { EU (28): 54.4; Turkey: 9.4; } \\
\text { Israel: 6.7; India: 4.2; } \\
\text { Chinese Taipei: 3.7; Other: } \\
21.6\end{array}$ \\
\hline Armenia & $\begin{array}{l}133 \\
106^{\mathrm{a}} \\
0.01^{\mathrm{b}}\end{array}$ & $\begin{array}{c}129 \\
102^{\mathrm{a}} \\
0.02^{\mathrm{c}}\end{array}$ & $\begin{array}{l}\text { Agricultural: } 27.9 ; \\
\text { Fuels and mining: } \\
\text { 38.4; Manufactures: } \\
22.5 \text {; Other: } 11.2\end{array}$ & $\begin{array}{l}\text { EU (28): } 28.7 \text {; Russian } \\
\text { Federation: } 26.9 \text {; } \\
\text { Switzerland: } 14.1 \text {; Iraq: } 6.3 \text {; } \\
\text { China: } 4.5 \text {; Other: } 19.5\end{array}$ \\
\hline Georgia & $\begin{array}{c}122 \\
96^{\mathrm{a}} \\
0.02^{\mathrm{b}}\end{array}$ & $\begin{array}{r}103 \\
77^{\mathrm{a}} \\
0.05^{\mathrm{c}} \\
\end{array}$ & $\begin{array}{l}\text { Agricultural: } 29.3 ; \\
\text { Fuels and mining: } \\
\text { 21.7; Manufactures: } \\
\text { 46.2; Other: } 2.9\end{array}$ & $\begin{array}{l}\text { EU(28): 21.7; Azerbaijan: } 15 \text {; } \\
\text { Russian Federation: } 13 \text {; } \\
\text { Armenia: } 8.5 \text {; Turkey: } 6.9 \text {; } \\
\text { Other: } 34.9\end{array}$ \\
\hline Kazakhstan & $\begin{array}{c}49 \\
32^{\mathrm{a}} \\
0.31^{\mathrm{b}}\end{array}$ & $\begin{array}{c}65 \\
44^{\mathrm{a}} \\
0.16^{\mathrm{c}}\end{array}$ & $\begin{array}{l}\text { Agricultural: } 5.2 \text {; } \\
\text { Fuels and mining: } \\
\text { 79.6; Manufactures: } \\
\text { 15.2; Other: } 0\end{array}$ & $\begin{array}{l}\text { EU(28): 50.9; China: } 10.3 \text {; } \\
\text { Russian Federation: } 8.5 \text {; } \\
\text { Korea, Republic of: } 4.9 \text {; } \\
\text { Switzerland: } 4.7 \text {; Other: } 20.7\end{array}$ \\
\hline $\begin{array}{l}\text { Kyrgyz } \\
\text { Republic }\end{array}$ & $\begin{array}{l}141 \\
114^{\mathrm{a}} \\
0.01^{\mathrm{b}}\end{array}$ & $\begin{array}{l}131 \\
104^{\mathrm{a}} \\
0.02^{\mathrm{c}}\end{array}$ & $\begin{array}{l}\text { Agricultural: } 15.1 ; \\
\text { Fuels and mining: } \\
\text { 15.4; Manufactures: } \\
\text { 31; Other: } 38.5\end{array}$ & $\begin{array}{l}\text { EU(28): 44.9; Russian } \\
\text { Federation:16.1;Kazakhstan:1 } \\
\text { 3; Uzbekistan: 9.4; Turkey: } \\
\text { 6.2; Other: } 10.4\end{array}$ \\
\hline Tajikistan & $\begin{array}{l}149 \\
122^{\mathrm{a}} \\
0.01^{\mathrm{b}}\end{array}$ & $\begin{array}{l}151 \\
124^{\mathrm{a}} \\
0.01^{\mathrm{c}}\end{array}$ & $\begin{array}{l}\text { Food items 10; } \\
\text { Agricultural raw } \\
\text { materials: } 17 ; \text { Fuels } \\
\text { 7; Ores and metal: } 36 ; \\
\text { Manufactures: } 18 ; \\
\text { Other: } 12\end{array}$ & $\begin{array}{l}\text { Top } 5 \text { partners: Turkey: } 16,0 \text {; } \\
\text { Switzerland, } \\
\text { Liechtenstein:12,8; China: } \\
\text { 10.8; Russian Federation: } \\
\text { 10,3; Kazakhstan: } 9,6\end{array}$ \\
\hline Turkmenistan & $\begin{array}{c}91 \\
66^{\mathrm{a}} \\
0.05^{\mathrm{b}}\end{array}$ & $\begin{array}{c}150 \\
123^{\mathrm{a}} \\
0.01^{\mathrm{c}}\end{array}$ & $\begin{array}{l}\text { Agricultural raw } \\
\text { materials: 11; Fuels: } \\
77 \text {; Manufactures: } 10 \text {; } \\
\text { Other: } 1\end{array}$ & $\begin{array}{l}\text { Top } 5 \text { partners: China: } 65.1 \text {; } \\
\text { Ukraine } 6,35 \text {; Afghanistan } \\
6,3 \text {; Iran } 4,9 ; \text { Turkey: } 4,1\end{array}$ \\
\hline
\end{tabular}




\begin{tabular}{|c|c|c|l|l|}
\hline & & & Food: 9; Energy (e.g. & China16.3; Russian \\
& 85 & 82 & gas): 20.2; Machinery & Federation: 12.0; Kazakhstan: \\
& $60^{\mathrm{a}}$ & $57^{\mathrm{a}}$ & \& equipment: $1.6 ;$ & 10.9; Turkey: 8.0; Kyrgyz \\
Uzbekistan & $0.06^{\mathrm{b}}$ & $0.09^{\mathrm{c}}$ & $\begin{array}{l}\text { Other (e.g. gold, } \\
\text { textiles): } 29.4\end{array}$ & $\begin{array}{l}\text { Republic: } 4.3 ; \text { Afghanistan: } \\
\text { 3.5; EU(27): } 2.4\end{array}$ \\
\hline
\end{tabular}

Notes: a- Excluding intra-EU trade ; b- Share in world total exports (2018\%); c-Share in world total imports (2018\%); Compiled by the authors

Conditions for trade are now improving. Kazakhstan, Kyrgyzstan and Tajikistan - the three Central Asian countries (except for Turkmenistan and Uzbekistan) already belong to the WTO; Kyrgyzstan is the Central Asian GSP participant at present, Uzbekistan, which has cut tariffs, plans to become member WTO, and also hopes to join the EU's GSP scheme, which would give its exports preferential access to EU markets. Also, opening to international trade is not a sufficient condition to increase economic growth, other factors such as infrastructure, investment, industrial development, protectionist policies, and technology progress need to be effective, the incidence of political instability negatively affects food security. Some researchers find similar results for ECOWAS, ASEAN, emerging and most commodity-dependent developing countries $[15,16,17]$. While the SC\&CA has made significant progress in integrating with the rest of the world, intra-regional trade has yet to expand. IMF (2014) staff report on the regional economic outlook and key challenges noted that, despite rapid economic growth, the share of intra-regional trade in the SC\&CA relative to the region's overall global trade dropped significantly over the past two decades.

International trade has experienced three major structural changes since the 1990s [18]: The first change is the 'servicification' of trade, the second key phenomenon affecting trade has been the globalization of firms' value chains, whereby intermediate rather than final goods (and services) are also traded internationally; finally, with the economy's digitization, goods and services are increasingly traded in digital rather than physical form. As a result, international trade agreements have evolved to reflect these changes. The international integration relations of the SC\&CA countries need to cope with the profound and various geo-economic and geopolitical shifts set in motion by the energy transition, the new industrial revolution (Industry 4.0) and new "grid communities". Energy-rich and other nations of SC\&CA are partners in Eastern Partnership (EaP), EAEU and China's Belt and Road Initiative. Diversifying the economy, foreign trade and investment ties could give South Caucasus and Central Asian countries more influence over how a changing global order plays out in the region.

\section{Methodology}

Here we present a simple sector neoclassical model to illustrate the effects of the globalization on structural transformation in open economies. The model builds on Heckscher-Ohlin model and its dynamic extensions. The model also relates to the literature studying trade flows in the context of the process globalization and new regionalizm (WTO, UNCTAD, IMF). We split the region into two groups of countries, in terms of their international specialization ${ }^{3}$ : oil\&gas exporters and oil\&gas importers-both are open to international trade.In theory at least, the potential in exploiting the neighbouring markets in both the SC and CA region might be a good opportunity worthy of exploration. A number studies were held on the subject of the problems and challenges of complex transformation and development strategies. The economic and political pattern that started to develop in SC\&CA regions was based on the liberal market economy model with the objective

${ }^{3}$ SC\&CA oil and gas exporters: Azerbaijan, Kazakhstan, Turkmenistan, and Uzbekistan; SC\&CA oil and gas importers: Armenia, Georgia, Kyrgyz Republic, and Tajikistan. 
integrating them into the world economy. From this perspective the proximity of the big EAEU and China markets to SC\&CA and the proximity of the EU and Turkey market to the $\mathrm{SC}$ region are worth taking into account.

We specifically focused on trade trends that intended to affect inclusive growth; however, some researches with broad development and policy themes were included because of their mention globalization and international integration. Researches that focused on the improvement of infrastructure were included because of the inherent link between wellfunctioning interaction systems and also ability to access the new opportunities. Moreover, most researches included did not propose concrete indicators. In understanding the narratives, we also attempted to discover the underlying issue or motives possessed by the region countries in their interest in shaping the future cooperation.

The paper would therefore like to recommend that while highlighting trade linking as a globalization goal, future proposals should include international integration and growth targets to ensure the economic space are fully harmonized.

\section{Results}

Trade globalization is the most powerful mechanism to promote development in the SC\&CA region and supports economic transformation and growth. Countries have not been able to transform economically without focusing on diversification and competitiveness. The removal of barriers to trade is necessary, but not sufficient for development. There has been a negative perception on the role of the free trade and integration conception in the region in early economic transformation, but recent WTO members data suggest that trade is a major contributor to connection and regional interaction. Globalization Models and ideas, however, do not always result in significant accomplishments. Even the most developed institutional exercise of regional integration, the European Union (EU), is commonly overwhelmed by the contradictions of the institutional architecture and the interests of the member states. Despite its ebbs and flows, the assessment of the European integration process is positive and still at the forefront of regional integration experiences [19].How an understanding of 'region' in the Asia Pacific will be constituted over the long term is yet to be determined [20].

The tendencies made clear that the regional neighbours depend on each other's for their economic well-being, their own economic future is dependent not only on own strategy and results, but on the region partners as well. While a single economic plan for the whole region $\mathrm{SC}$ and $\mathrm{CA}$ is not possible given the differing geographies and resources of constituent countries, it is realistic to aim for greater coherence, synergy and momentum in the pursuit of collective strategies. In globalization conditions economic development SC (Azerbaijan, Georgia) \& CA (Kazakhstan, Kyrgyzstan and Uzbekistan) critically involves diversification and structural transformation - that is, the continued, dynamic reallocation of resources from less competitive to more productive activities. And the trend is clear. This process involves not just external trade, but the broader logistic and services.

Azerbaijan, Kazakhstan and Uzbekistan have contributed to such a process in recent years. Keenly aware of their economic interdependence with Europe and other immediate neighbours (Russia, China), have also been particularly open to other economic and political partners. They are now a good example of the type of multi-vector economic foreign policy and structural transformation in the region.

As Kazakhstan is the second most important member of the Eurasian Economic Union and the EU partnership with the coun-try will be crucial for promoting EU standards in the region. Kazakhstan - along with Uzbekistan - will be a crucial partner for the EU in Central Asia. Aiming at economic diversification and encouraging FDI in the manufacturing sector, thus opening up chances for European business in named countries. Indeed, the lessons included avoiding fragmentation of cooperation among the region nations. Which need to get 
the right rules in place so the interaction system is more resilient, more beneficial, and more integrative? International institutions WTO, EU and ADB have a difficult but indispensable role in helping to bring more of globalization's benefits to the countries throughout the region.

Apparently, there is little chance of a Central Asian single market. Kazakhstan and Kyrgyzstan's membership of the Eurasian Economic Union bars them from such arrangements with non-EAEU countries, except as part of wider agreements that extend to all EAEU member states. Nevertheless, the region is a stretch space that inspires EU efforts to promote international connecting and regional interaction. At the same time, the integration approach is not a comprehensive one. The EAEU enables the free movement of people and goods, but not by building transregional infrastructure but also by dismantling regulatory barriers and promoting cooperation in a narrow range of areas.

On the basis of data compiled by a variety of sources, including the international and regional organizations, it can be concluded that the concept of international economic cooperation in the region could have balanced. Results from research taking into account the geographical differences, different path of the transformation in the region countries, and the various their participation in integration projects and tends of their economic interactions supported our hypotheses.

\section{Discussion}

The oil nations of Caucasus and Central Asia are hoping that a combination of reforms, privatisation and infrastructure investment will protect them against the downturn in the oil and gas markets. Even the Gulf Cooperation Council (GCC) the unquestioned kingpin of the oil market, is moving in this direction: to diversify the oil economy. Governments in Bahrain, Kuwait, Oman, Qatar, Saudi Arabia and the United Arab Emirates have mobilized the global knowledge and development experience through technical assistance programs WB over the years. Azerbaijan and Kazakhstan have come up with a combination of reforms, infrastructure and efforts to regional cooperation new life into economies and create a path for post-oil economic growth in the region. Nonetheless, the potential benefits from structural transformation, in which the countries boasts a large untapped potential, initiatives are by no means certain because the country's limited production base reduces its capacity to export and compete in broader economic blocs. Most diversification projects are long-term and will not generate additional cash or jobs in the first phase of implementation, but could be difficult to sustain in light of the current crisis [21].

Agricultural-food trade in the South Caucasus and Central Asia (SC\&CA) countries is highly dependent on neighbour regional markets, primarily on Russian Federation. Close trade relations within the CIS countries are mainly explained by traditional ties, common borders and transportation infrastructure, as well as agricultural specialization inherited from the former Soviet Union. However, substantial changes have occurred in trade policies of the SC\&CA countries during the previous decade. Agricultural and natural resources tend to have lower potential for quality upgrading than manufactures. If agriculture is land intensive, agricultural technical change increases the return to land and reduces the return to capital [22].Expansion of the Eurasian Economic Union (EAEU), accession of several region countries to the WTO and trade tensions between Russia and the western countries play an important role in determining the directions of agricultural trade in the region. The transformative influence emerging from these developments and the implications for the SC\&CA economies are not yet fully conceived because the study finds little evidence of overt transformation. Economic environment and conditions are changing, with ever greater emphasis on globalization impact. But the real world doesn't work like merely on linear way - impact emerges from many influences. 
Admittedly, the transformation of businesses and corporate governance in SC\&CA is not accidental, which is still fairly weak. Azerbaijan and Kazakhstan is aided by the fact that their governments in the region have pro-business diversification policies and helped new tech develop very fast, the level of education in Azerbaijan, Kazakhstan and Georgia has increased tremendously. But there are many areas where SC\& CA countries will need to continue improving, to realize their full potential, the standards of corporate governance are relatively behind western standards.

Especially, In the life of the organization, the change in external and the internal legal form of the relationship, socio-economic conditions requires serious modernization of the system of foreign economic activity management at all levels (which are macro, mesa and micro), a change in external and internal conditions of business creates the real environment for better meeting on existing and emerging needs of the population [23].

The main problem for Regional and International Cooperation in Central Asia and South Caucasus to find fundamentally new sources of economic growth and a new place in the twenty-first century global economy and system of global values. Under trade globalization the raw based structure of the economy has been an underlying characteristic of many SC\&CA economies. Concentration in sectors with limited scope, such as primary commodities, may result in less sustainable growth. Moreover, lack of diversification may increase exposure to adverse external shocks and macroeconomic instability of globalization.

Furthermore, alternative (and competing) visions for the future energy system are being pushed by powers such as China and the United States. This affects not only global transformation processes, but also estab-lished partnerships - both within the EU and with third countries, ultimately erod-ing multilateral energy governance mechanisms in favor of economic fragmentation and technological-normative competition [24].

Finally, there has been an added challenge - the crisis of Covid-19, which has already pro-foundly affected regional and international economy and will have long-lasting repercussions in the years to come .The globalization priorities in the region are changing: This was followed by the future plans of countries in response to the Covid-19 pandemic. As we can already see from slumping global oil prices on the global market, the corona crisis will not only affect the stability of economies that are dependent on the export of fossil fuels, but also the World economy. Aside from this immediate shock, mid-term effects on the global scale include the disruption of global value chains. GVCs will remain at the centre of future economic debates and, especially, in the context of the recent protectionist tensions and regional disintegration pressures in NAFTA and the EU [25]. It is clear that up-to-date measures of this phenomenon are crucial for analyses of the globalization process in SC\&CA countries.

\section{Conclusions}

The transformative impacts of trade globalization on economic development and regional integration are a subject of debate in the existing literature: the impacts were found to be positive in some field and nonsignificant or even negative in others. In setting the new priorities, the region will need to strike a balance between global aspirations and limited regional means. The upcoming transformation and diversification process is being called to step up efforts to upgrade the countries' economy along three lines. First, to review the existing set of priorities accord-ing to the new challenges. Second, expand the global spatial radius of its actions beyond its direct neighborhood by focusing on EU and other global partners, also step up efforts the existing cross-border connections and missing links on the internal SC\&CA borders. Third, upgrade its instruments toolbox along new areas of action, in favor of global competitiveness of economy. 
The globalization priorities in the world are to some extent changing: This was followed by the future plans of SC\&CA countries in response to the Covid-19 pandemic - the crisis, which has already pro-foundly affected regional and international economy and will have long-lasting repercussions in the years to come.

Given the processes under way, the transformation process of SC\&CA region will face a complex test of balancing, energy industrial, trade, development, as well as security policies - in bi- and multilateral formats.

Finally, and most importantly, the ongoing fragility of the region will not be fixed anytime soon as the region is prone to domestic instability, protracted conflicts. Transformation must be equipped with essential feature- strategic patience, own strategic interests and common values, take into account the developments in the partner countries.

The global transformation, the need for diversification, the growing domestic demand in both subregions can potentially create a good basis for increased economic exchange. Economic cooperation between the SC\&CA countries may serve as a complementary channel to the strategic orientations of both subregions. From this perspective, the outcome of international trade and investment projects and new relationship may change the picture.

The world and region countries and the international organizations should seek security in the South Caucasus by being prepared uncertain domestic and regional environment. Also, the SC\&CA countries will need to adopt a more flexible bilateral approach complemented by renewed multilateral cooperation formats via transformation.

The theme and research of this paper is continuation of joint research work on the field of economic globalization, international integration and development after the release of our joint book "Global Competitiveness", ISBN 978-9952-435-67-2, in 2016, in Azerbaijani.

\section{References}

1. Stiglitz, J. (2003). Globalization and Its Discontents, New York: W.W. Norton \& Company.

2. Fioretos, O., Heldt, E. C. (2019). Legacies and innovations in global economic governance since Bretton Woods. Review of International Political Economy, 26(6), 1089-1111.

3. World Economic Forum (2014, September 10). Scenarios for the South Caucasus and Central Asia. Retrieved from: http://www3.weforum.org/docs/WEF_Scenarios_ SouthCaucasusCentralAsia_Report_2014.pdf.

4. Bohr, A. (2004). Regionalism in Central Asia: New Geopolitics, Old Regional Order. International Affairs, 80(3), 485-502.

5. Boonstra, J., Delcour, L. (2015). A broken region: evaluating EU policies in the South Caucasus, Policy Brief, 193, 1-6.

6. Acharya, A. (2018). The Endof the American World Order. $2^{\text {nd }}$ edition. Cambridge: Polity.

7. Contessi, N. P. (2016). Central Asia in Asia: Charting growing trans-regional linkages. Journal of Eurasian Studies, 7(1), 3-13.

8. Santander, S. (2018). Regionalism in a globalised multipolar economy. Civitas - Revista de Ciências Sociais, 18(2).

9. Caselli, F., Koren, M., Lisicky, M., Tenreyro, S. (2019). Diversification Through Trade. The Quarterly Journal of Economics, 135(1), 449-502.

10. Kohli, H. S., Linn, J. F., Zucker, L. M. (2020). China's Belt and Road Initiative: Potential Transformation of Central Asia and the South Caucasus. SAGE Publications. 
11. Russell, M. (2019). Connectivity in Central Asia Reconnecting the Silk Road. EPRS European Parliamentary Research Service. Retrieved from: https://www.europarl. europa.eu/RegData/etudes/BRIE/2019/637891/EPRS_BRI(2019)637891_EN.pdf

12. Candelon, B., Carare, A., Hasse, J-B., Lu, J. (2020). The post-crises output growth effects in a globalized economy. International Economics, 161, 139-158.

13. Middle East and Centrral Asia Department (2014). The Caucasus and Central Asia: transitioning to emerging markets. Retrieved from: https://www.imf.org/external/pubs/ft/dp/2014/1402mcd.pdf

14. Vera-Martín, M., Fayad, D., Saksonovs, S., Shi, W., Yang, F. (2019). Promoting Inclusive Growth in the Caucasus and Central Asia. Retrieved from: https://www.elibrary.imf.org/view/IMF087/26024-9781498313353/260249781498313353/26024-9781498313353_A001.xml?language $=$ en\&redirect $=$ true

15. Tinta, AA., Sarpong, DB., Ouedraogo, IM., Al Hassan, R., Mensah-Bonsu, A., Onumah, EE. (2018). The effect of integration, global value chains and international trade on economic growth and food security in ECOWAS. Cogent Food \& Agriculture, 4(1), 1465327.

16. Li, B. G., Gupta, P., Yu, J. (2017). From natural resource boom to sustainable economic growth: Lessons from Mongolia. International Economics, 151, 7-25.

17. Botev, J., Égert, B., Jawadi, F. (2019). The nonlinear relationship between economic growth and financial development: Evidence from developing, emerging and advanced economies. International Economics, 160, 3-13.

18. Leblond, P., Viju-Miljusevic, C. (2019). EU trade policy in the twenty-first century: change, continuity and challenges. Journal of European Public Policy, 26(12), 18361846.

19. Roy, J., Dominguez, R. (2005). The European Union and Regional Integration. A Comparative Perspective and Lessons for the Americas. Retrieved from: http://aei.pitt.edu/32456/1/The_EU-Regiional-text\%2 Bcover-final.pdf

20. Higgott, R., Stubbs, R. (1995). Competing conceptions of economic regionalism: APEC versus EAEC in the Asia pacific. Review of International Political Economy, 2(3), 516535.

21. Guliyev, M. (2020). Accelerating Economic Diversification In Azerbaijan: Challenges, Shaping Prospects. 56th International Scientific Conference on Economic and Social Development (pp. 352-360). Varazdin: Varazdin Development and Entrepreneurship Agency (VADEA).

22. Bustos, P., Garber, G., Ponticelli, J. (2020). Capital Accumulation and Structural Transformation. The Quarterly Journal of Economics, 135(2), 1037-1094.

23. Huseynova, K. (2014). Marketing policy in the context of integrating it into World Economy. The Business \& Management Review, 5(3), 65-68.

24. Pastukhova, M., Pepe, J. M., Westphal, K. (2020). Beyond the Green Deal: Upgrading the EU's Energy Diplomacy for a New Era. Stiftung Wissenschaft und Politik. Retrieved from: https://www.swp-berlin.org/10.18449/2020C31

25. Gaulier, G., Sztulman, A., Ünal, D. (2020). Are global value chains receding? The jury is still out. Key findings from the analysis of deflated world trade in parts and components. International Economics, 161, 219-236. 